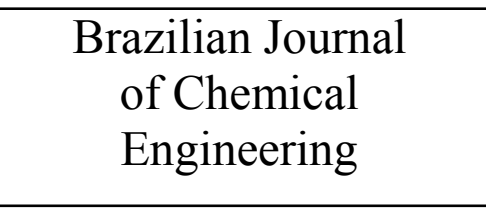

ISSN 0104-6632

Printed in Brazil www.abeq.org.br/bjche

Vol. 24, No. 04, pp. 571 - 585, October - December, 2007

\title{
INTERMITTENT DRYING OF BEANS IN A SPOUTED BED
}

\author{
C. A. Oliveira and S. C. S. Rocha* \\ Chemical Engineering School, State University of Campinas, UNICAMP, \\ Phone: +(55) (19) 3521-3929; Fax: +(55) (19) 3521-3922, C.P. 6066, \\ Barão Geraldo, CEP: 13083-970, Campinas - SP, Brazil \\ E-mail: rocha@feq.unicamp.br \\ (Received: March 03, 2006 ; Accepted: September 01, 2007)
}

\begin{abstract}
Carioca beans are a highly nutritious grain, in terms of the amount of protein, iron and potassium as well as carbohydrates and fiber and as a source of vitamins. The moisture content of recently picked beans is too high for good preservation and storage, resulting in the need for drying before packaging. In this work, the drying of Carioca beans in a laboratory scale spouted bed under intermittent conditions of the drying air was experimentally analyzed. Experiments carried out consisted of two types of intermittent regime: intermittence in the spout regime, referred to as spouted/fixed bed and intermittence of the air supply to the bed, called spouted bed/rest. The results were compared to those for bean drying in a spouted bed dryer without intermittence.

Keywords: Drying of grains; Drying kinetics; Energy efficiency.
\end{abstract}

\section{INTRODUCTION}

Seeds and grains, in general, are considered important products of high nutritious value. Phaseolus vulgaris L. is the most common variety of beans, being responsible for about $95 \%$ of the world production. It is a very important source of calories in the human diet, mainly in developing countries in tropical and subtropical regions. Phaseolus vulgaris L. beans of the carioca variety are produced and consumed in large quantities in Brazil. The advantages on consuming beans are the high content, of proteins, such as lysine, which has a complementary effect on the cereal proteins, their dietary fiber and their high content of carbohydrates, minerals and B complex vitamins (Lajolo et al., 1996).

The storage of grains in Brazil, where it was verified that $30 \%$ of the crop was lost by lack of good storage conditions, has been included in several government programs, providing incentives for the construction of big warehouses. Grains, generally, when picked in the field, have a high moisture content. Considering storage and conditioning, it becomes essential to decrease the moisture content of grains through an efficient drying process.

Use of the spouted bed dryer for grain drying has been studied and good results in terms of final moisture as well as good quality products with homogeneous moisture content and temperature have been obtained (Lima and Rocha, 1998; Robins and Fryer, 2003; Madhiyanon et al., 2001, 2002; Wiriyaumpaiwong et al., 2003; Wachiraphansakul and Devahastin, 2005).

However, energy efficiency of the process is low and attrition in the spouted bed may render it impracticable, mainly for drying grain seeds.

The choice and design of the dryer, the operating conditions and the effect of these parameters on the quality of the final product are very important

*To whom correspondence should be addressed 
characteristics to take into account in an analysis of grain drying (Sangkram and Noomhorm, 2002; Inprasit and Noomhorm, 2001). As most grains become fragile in a moving bed and fluidized or spouted bed dryer due to their exposure to severe attrition conditions, the use of an intermittent drying process could be profitable and necessary to maintain product quality.

The drying of particulate materials can be carried out in three different regimes: batch, continuous and intermittent. Intermittence in the operating conditions is determined by a periodic stop in the air supply to the bed or in the fluid-dynamic regime. Thus, it is possible to smooth out the process by decreasing losses due to mechanical attrition (Jumah and Mujumdar, 1996).

Keeping these considerations in mind, the aim of this work was to analyze the drying behavior and evaluate the energy efficiency of the bean-drying process in intermittent spouted/fixed bed and spouted bed/rest regimes and to compare the results with the ones obtained in a spouted bed without intermittent operation.

\section{MATERIAL AND METHODS}

\section{Characterization of the Material}

The experiments were conducted with grains of Phaseolus vulgaris L, carioca variety beans. These grains have the following characteristics: a short oblong shape, a cream colored tegument, with stripes; and an average mass of 34 grams for 150 grains.

Grain density was determined by pycnometry. Average diameter was measured with a caliper. It was defined as the equivalent volume sphere diameter. Sphericity was determined by the method proposed in Mohsenin (1978). According to this method, the particle is assumed to be an ellipsoid and sphericity is evaluated with Equation (1). To calculate particle volume (ellipsoid volume), particle dimensions were measured with a caliper. The circumscribed sphere diameter was obtained for the particle projection. Around 100 grains were used to calculate the average values of these properties. The physical properties determined for the beans are presented in Table 1.

$\phi=\left[\frac{\text { particle volume }}{\text { circumscribed sphere volume }}\right]^{1 / 3}$

\section{Experimental System and Drying Process}

The commercial grains available for use in the tests had moisture contents below the range necessary for development of the experiments. Grains were rewetted to obtain the initial grain moisture content at the values fixed in the experimental design. Beans are classified as hygroscopic material. Thus, their moisture content can be modified in an atmosphere where the partial pressure of water in the gas phase is different from that inside the grains. With this principle in mind, a rewetting system was designed and constructed in this work to alter the initial moisture content of the grains to the desired values for the drying experiments. The rewetting system was composed of four screened trays arranged vertically above a water tank. The water was electrically heated and recirculated in the tank using a small pump. A temperature controller maintained the water temperature constant. The trays could be exchanged any time. Preliminary tests were conducted to evaluate the time necessary for a fixed mass of grains to attain the desired moisture contents. The rewetting system utilized is illustrated in Figure 1.

The drying system designed and constructed for this work as well as the bed dimensions are presented in Figure 2.

Table 1: Physical properties of the carioca beans

\begin{tabular}{|c|c|c|}
\hline $\begin{array}{c}\text { Density } \\
\left(\mathbf{k g} / \mathbf{m}^{\mathbf{3}}\right)\end{array}$ & $\begin{array}{c}\text { Average Diameter } \\
(\mathbf{m m})\end{array}$ & Sphericity \\
\hline $755 \pm 5$ & $7.34 \pm 0.23$ & $0.460 \pm 0.003$ \\
\hline
\end{tabular}



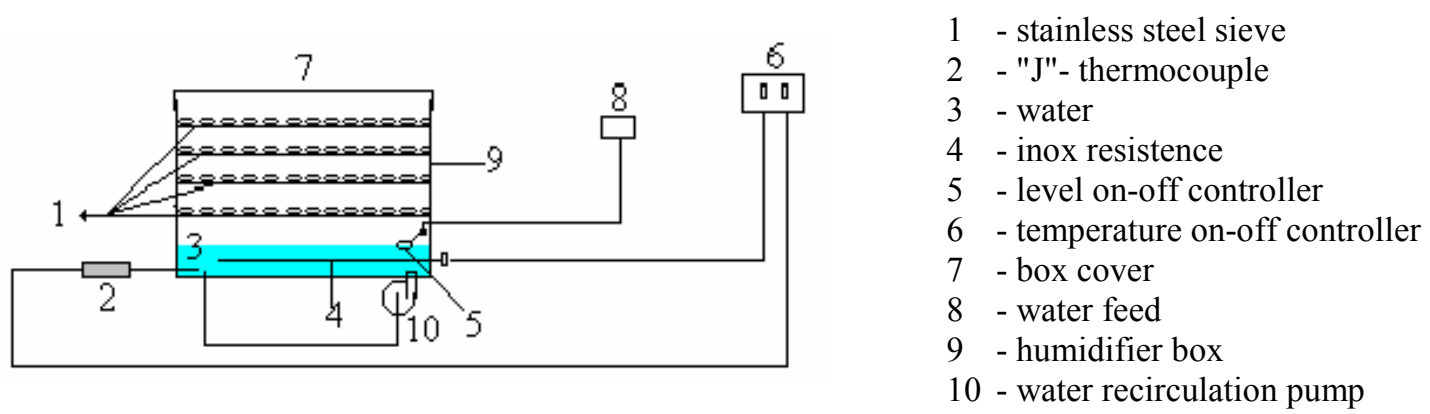

Figure 1: Grains rewetting system

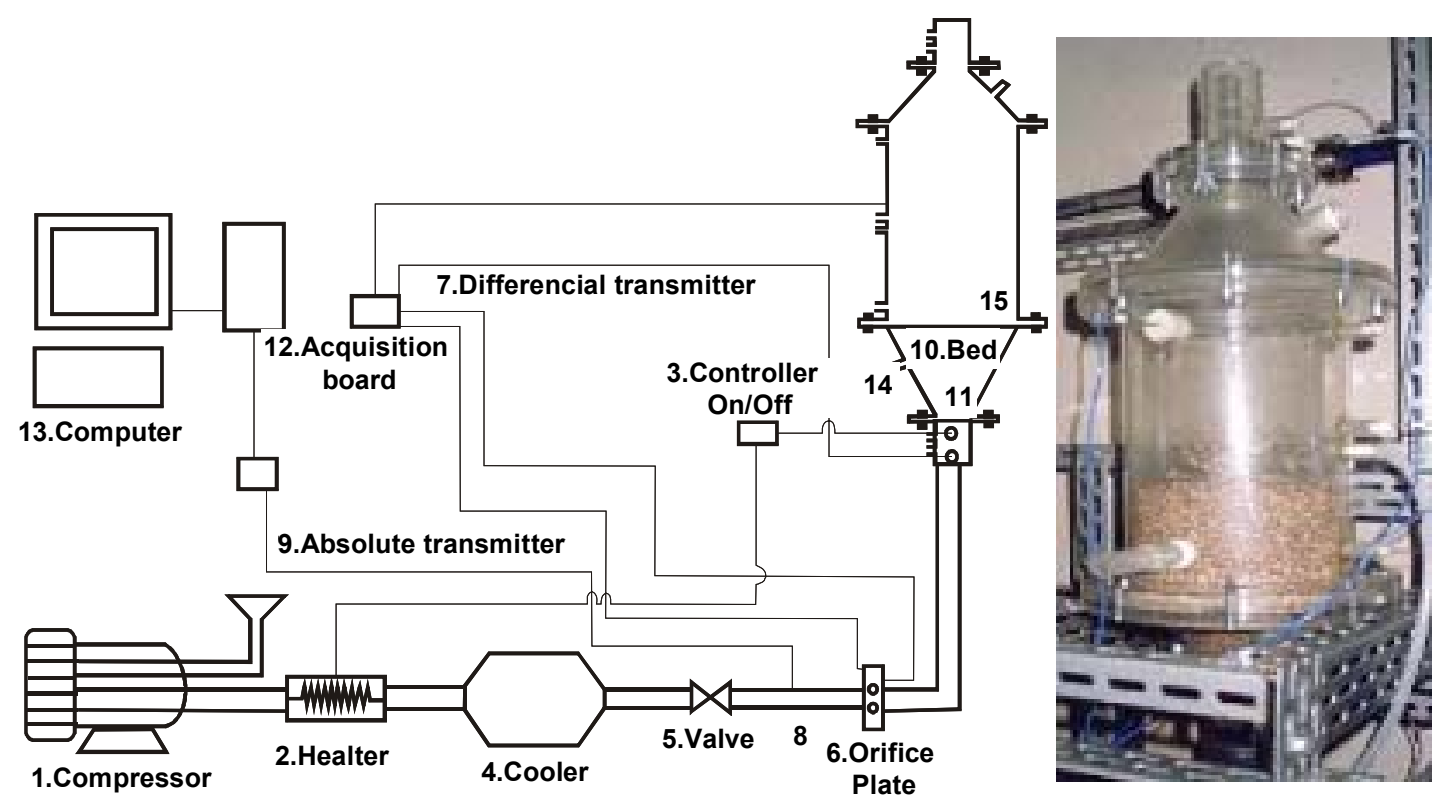

(a)

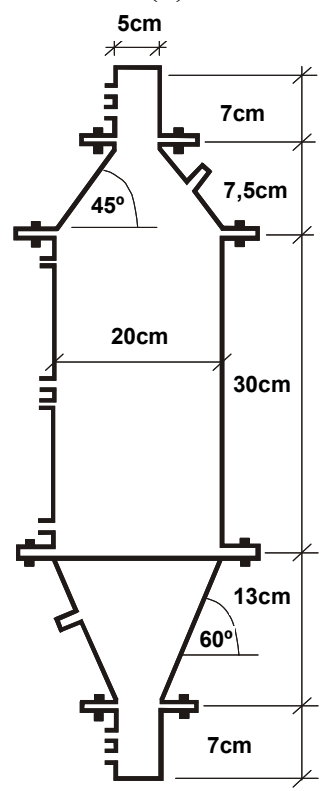

(b)

Figure 2: Experimental system - (a) scheme and sight of the bed filled with beans;

(b) bed dimensions 
The drying system comprise a compressor (1), which supplied air to the bed of grains, which was heated by means of three resistances (2). The air temperature was controlled by an on-off controller (3). The cooler (4) was used to maintain the temperature at the required levels when the compression overheated the drying air. The cooler was made of aluminum plate and copper tubes and used water as the cooling fluid. The airflow rate was set by a valve (5) and measured with an orifice meter (6) by a differential pressure transmitter (7). The static pressure line (8) was obtained by the absolute transmitter (9).

The pressure transmitters were connected to the A/D data acquisition board (12). The distribution plate (11) was used to provide a uniform distribution of air to the bed (10). Particle samples were taken at the bed wall (15) and the solids were discharged through a small tube (14). The data acquisition board was controlled with the software Labtech - Version 9.0, which allowed treatment of the measurements in real time.

The experiments were conducted according to two types of intermittent process: spouted/fixed bed and spouted bed/rest, which will here be called processes I and II, respectively.

In process I (spouted/fixed bed), the bed was loaded with the grains (after attaining thermal equilibrium) and put to spout under a stable spout operating condition. The air flow rate was then periodically decreased until the spout collapse and the bed of beans was maintained fixed. The air flow rate was maintained constant at the condition of fixed bed of beans for a period of time defined as the intermittence time, $\mathrm{t}_{\mathrm{i}}$. Then, the bed was again put to spout by increasing the air flow rate to the previous value of stable spout condition, for the same period, $t_{\mathrm{i}}$. The same procedure was repeated for 240 min of total drying.

Intermittence process II (spouted bed/rest) was similar to process $\mathrm{I}$, but at the intermittent time, $\mathrm{t}_{\mathrm{i}}$, the air flow to the bed was totally interrupted. After $t_{i}$ minutes of interruption of the air flow to the bed, the air supply was restored under the stable spout condition. The procedure was repeated until $240 \mathrm{~min}$ of drying time.

To summarize, in process I the intermittence of the fluid-dynamic regime resulted in spouted bedfixed bed-spouted bed-fixed bed, while in process II the result was spouted bed-interruption of the air supply-spouted bed- interruption of the air supply.

The factorial design technique was applied to define the experiments and to allow a statistical analysis of the results (Box et al., 1978). Eight drying runs were conducted for each intermittent process, I and II, as defined above. The values of three variables (initial moisture content of the grains,
$\mathrm{X}_{0}$; drying air temperature, $\mathrm{T}_{\mathrm{ar}}$; and intermittence time, $\mathrm{t}_{\mathrm{i}}$ ) were changed at two levels, and their effects were analyzed on the response: final moisture ratio, $\mathrm{X}_{\mathrm{f}} / \mathrm{X}_{0}$, determined at $240 \mathrm{~min}$ of drying. Thirteen grain samples were collected during each drying experiment to determine the drying kinetics and the grain temperature. Part of each sample collected was put in a calorimeter where a contact thermocouple recorded the grain temperature. The moisture content of the particles was determined by the static oven method at a constant temperature of $105 \pm 3{ }^{\circ} \mathrm{C}$ until constant weight was achieved. The drying rate was numerically determined using the experimental data in the drying curves.

The drying kinetics and the grain temperature curves were compared with previous results of the same process without intermittence. The same procedure was followed to rewet the grains and conduct the previous experiments in the spouted bed without intermittence. Also, the same type of beans was used and the same producer furnished the grains. However, it is worth pointing out that the grains used in both cases were of different harvests and different years, and thus a possible variation in raw materials could have affected the comparison of the results.

The energy flux of the drying process was evaluated for the 16 experiments, based on three energy coefficients DE, DC and FC (Lima and Rocha, 1998; Pakowski and Mujumdar, 1995; Lima, 1996; Dewettinck et al., 1999). The drying efficiency flux, DE, was defined as the energy necessary to heat up the grains and to evaporate the water in relation to the total energy supplied to the operation (Eq. 2). The drying coefficient, DC, was defined as the amount of water evaporated by the amount of energy supplied to the operation (Eq. 11). The fluiddynamic drying coefficient, FC, represents the ratio of the energy spent to vaporize the water to the mechanical energy required to pump the air (Eq. 12) and was used to compare the fluid-dynamic aspects of drying processes I and II.

$\mathrm{DE}=\frac{\mathrm{E}_{\mathrm{h}, \mathrm{g}}+\mathrm{E}_{\mathrm{v}, \mathrm{w}}}{\mathrm{ET}}$

The energy flux required to heat up the grain from its initial temperature to the final temperature was calculated as proposed in Strumillo and Kudra (1986):

$E_{h, g}=m_{g, d r y} \cdot\left(c_{g f} \cdot T_{g f}-c_{g 0} \cdot T_{g 0}\right) / t_{h, g}$

The specific heat of the grain was obtained by

$c_{g}=\frac{c_{g, d r y}+c_{w} \cdot X}{1+X}$ 
The energy flux required for moisture of the evaporation was

$\mathrm{E}_{\mathrm{v}, \mathrm{w}}=\Delta \mathrm{H}_{\mathrm{v}, \mathrm{w}} \cdot\left(\mathrm{m}_{\mathrm{g}, \mathrm{w}} / \mathrm{t}_{\mathrm{d}}\right)$

The latent heat of evaporation was considered as that required to evaporate the free water, which in agreement with Muthu and Chattopadhyay (1993) is valid for materials with high moisture contents. The authors obtained the following equations for heat of vaporization as a function of air temperature:

$\Delta \mathrm{H}_{\mathrm{v}, \mathrm{w}}=2502.535259-2.38576424 \cdot\left(\mathrm{T}_{\mathrm{ar}}+273\right)$

for $0^{\circ} \mathrm{C} \leq \mathrm{T}_{\mathrm{ar}} \leq 65.56^{\circ} \mathrm{C}$

$$
\Delta \mathrm{H}_{\mathrm{v}, \mathrm{w}}=\left[7329155.98-15.9959641 \cdot\left(\mathrm{T}_{\mathrm{ar}}+273\right)^{2}\right]^{1 / 2}
$$

for $65.56^{\circ} \mathrm{C} \leq \mathrm{T}_{\mathrm{ar}} \leq 260^{\circ} \mathrm{C}$

The total energy flux supplied to the operation, ET, was considered to be the sum of the thermal and mechanical energies.

$\mathrm{ET}=\mathrm{E}_{\text {ter }}+\mathrm{EM}$

The thermal energy supplied to the operation was calculated as

$\mathrm{E}_{\mathrm{ter}}=\mathrm{W}_{\mathrm{ar}} \cdot\left(\mathrm{c}_{\mathrm{ar}} \cdot \mathrm{T}_{\mathrm{ar}}-\mathrm{c}_{\mathrm{amb}} \cdot \mathrm{T}_{\mathrm{amb}}\right)$

The specific heat of the air was obtained in Welty et al. (1984).

The mechanical energy supplied to pump the air
$\mathrm{EM}=\Delta \mathrm{P} \cdot \mathrm{Q}$

$\mathrm{DC}=\frac{\mathrm{m}_{\mathrm{g}, \mathrm{w}} / \mathrm{t}_{\mathrm{d}}}{\mathrm{ET}}$

$\mathrm{FC}=\frac{\mathrm{E}_{\mathrm{v}, \mathrm{w}}}{\mathrm{EM}}$

The results of the energy analysis for the intermittent processes I and II were compared to each other and to previous results presented in Lima and Rocha (1998) and Lima (1996) for the spouted bed drying of beans without intermittence.

A statistical analysis of the results allowed verification of the effects of variables $X_{0}, T_{a r}$ and $t_{i}$ on energy coefficients DE, DC and FC.

\section{RESULTS AND DISCUSSION}

\section{Drying Analysis - Intermittent Drying}

Tables 2 and 3 show the experimental results for the final moisture content ratio, $\mathrm{X}_{\mathrm{f}} / \mathrm{X}_{0}$, obtained for each operating condition and the two types of intermittent process, I and II. In these tables, the values in brackets in the column for $\mathrm{X}_{0}$ represent rounded values (lower and higher levels) used to define the factorial design of experiments applied in this work. The experimental errors for the temperature and time measurements are $\pm 1{ }^{\circ} \mathrm{C}$ and \pm $0.0083 \mathrm{~min}$, respectively. The moisture contents were obtained by sample weighing using an analytical balance; measurement precision is of $0.0001 \mathrm{~g}$.

Table 2: Controlled variables and measured responses: Spouted/fixed bed - Drying process I

\begin{tabular}{|c|c|c|c|c|c|}
\hline Run & $\begin{array}{c}\mathrm{X}_{\mathbf{0}} \\
(\% \mathrm{db})\end{array}$ & $\begin{array}{c}\mathbf{T}_{\mathrm{ar}} \\
\left({ }^{\circ} \mathrm{C}\right) \\
\end{array}$ & $\begin{array}{c}\mathbf{t}_{\mathrm{i}} \\
(\mathrm{min})\end{array}$ & $\begin{array}{c}\mathbf{X}_{\mathrm{f}} \\
(\% \mathrm{db})\end{array}$ & $\mathbf{X}_{\mathrm{f}} / \mathbf{X}_{\mathbf{0}}$ \\
\hline 1 & $\begin{array}{c}31.73 \\
(30)\end{array}$ & 80 & 40 & 9.47 & 0.30 \\
\hline 2 & $\begin{array}{c}19.33 \\
(20)\end{array}$ & 80 & 40 & 9.17 & 0.47 \\
\hline 3 & $\begin{array}{c}28.53 \\
(30)\end{array}$ & 60 & 40 & 13.98 & 0.49 \\
\hline 4 & $\begin{array}{c}21.19 \\
(20)\end{array}$ & 60 & 40 & 13.00 & 0.61 \\
\hline 5 & $\begin{array}{c}29.97 \\
(30)\end{array}$ & 80 & 20 & 9.02 & 0.30 \\
\hline 6 & $\begin{array}{c}20.77 \\
(20)\end{array}$ & 80 & 20 & 9.23 & 0.44 \\
\hline 7 & $\begin{array}{c}29.11 \\
(30)\end{array}$ & 60 & 20 & 13.05 & 0.44 \\
\hline 8 & $\begin{array}{c}19.62 \\
(20)\end{array}$ & 60 & 20 & 12.99 & 0.66 \\
\hline
\end{tabular}


Table 3: Controlled variables and measured responses: Spouted bed/rest - Drying process II

\begin{tabular}{|c|c|c|c|c|c|}
\hline Run & $\begin{array}{c}\mathbf{X}_{\mathbf{0}} \\
(\% \mathbf{o d b})\end{array}$ & $\begin{array}{c}\mathrm{T}_{\mathrm{ar}} \\
\left({ }^{\circ} \mathrm{C}\right)\end{array}$ & $\begin{array}{c}\mathbf{t}_{\mathrm{i}} \\
(\mathrm{min})\end{array}$ & $\begin{array}{c}\mathbf{X}_{\mathbf{f}} \\
(\% \mathbf{o d b})\end{array}$ & $\mathbf{X}_{\mathrm{f}} / \mathbf{X}_{\mathbf{0}}$ \\
\hline 1 & $\begin{array}{l}32.5 \\
(30)\end{array}$ & 80 & 40 & 12.41 & 0.38 \\
\hline 2 & $\begin{array}{c}22.54 \\
(20)\end{array}$ & 80 & 40 & 11.58 & 0.51 \\
\hline 3 & $\begin{array}{c}31.40 \\
(30)\end{array}$ & 60 & 40 & 17.44 & 0.55 \\
\hline 4 & $\begin{array}{c}21.78 \\
(20)\end{array}$ & 60 & 40 & 15.35 & 0.70 \\
\hline 5 & $\begin{array}{c}30.03 \\
(30)\end{array}$ & 80 & 20 & 11.85 & 0.39 \\
\hline 6 & $\begin{array}{c}20.64 \\
(20)\end{array}$ & 80 & 20 & 13.85 & 0.67 \\
\hline 7 & $\begin{array}{c}30.11 \\
(30)\end{array}$ & 60 & 20 & 13.11 & 0.45 \\
\hline 8 & $\begin{array}{c}20.06 \\
(20)\end{array}$ & 60 & 20 & 12.83 & 0.64 \\
\hline
\end{tabular}

The lowest value for final moisture content of the beans obtained for process I was $\mathrm{X}_{\mathrm{f}}=9.02 \% \mathrm{db}$, which corresponds to the operating conditions $\mathrm{T}_{\mathrm{ar}}=$ $80^{\circ} \mathrm{C}, \mathrm{X}_{0}=20 \% \mathrm{db}$ and $\mathrm{t}_{\mathrm{i}}=20 \mathrm{~min}$, as shown in Table 2, run 5. For process II, the lowest final moisture content obtained for the beans was $11.58 \%$ $\mathrm{db}$, as can be seen in Table 3 for run 2. In this type of intermittent process, the operating conditions were $\mathrm{T}_{\mathrm{ar}}=80^{\circ} \mathrm{C}, \mathrm{X}_{0}=20 \% \mathrm{db}$ and $\mathrm{t}_{\mathrm{i}}=40 \mathrm{~min}$. For both processes, the lowest moisture content was obtained at the highest temperature, as expected. Although higher values of final moisture content were obtained for the spouted bed/rest intermittent process, both values of the lowest $\mathrm{X}_{\mathrm{f}}(9.02 \% \mathrm{db}$ and $11.58 \% \mathrm{db})$ are in the range specified as good storage conditions for carioca beans $\left(9.0 \% \leq \mathrm{X}_{\mathrm{f}} \leq 13.0 \% \mathrm{db}\right)$ (Cavalcanti Mata, 1997). Figures 3 to 6 are examples of drying curves and grain temperature curves obtained in the experiments (all the experiments show the same qualitative behavior).

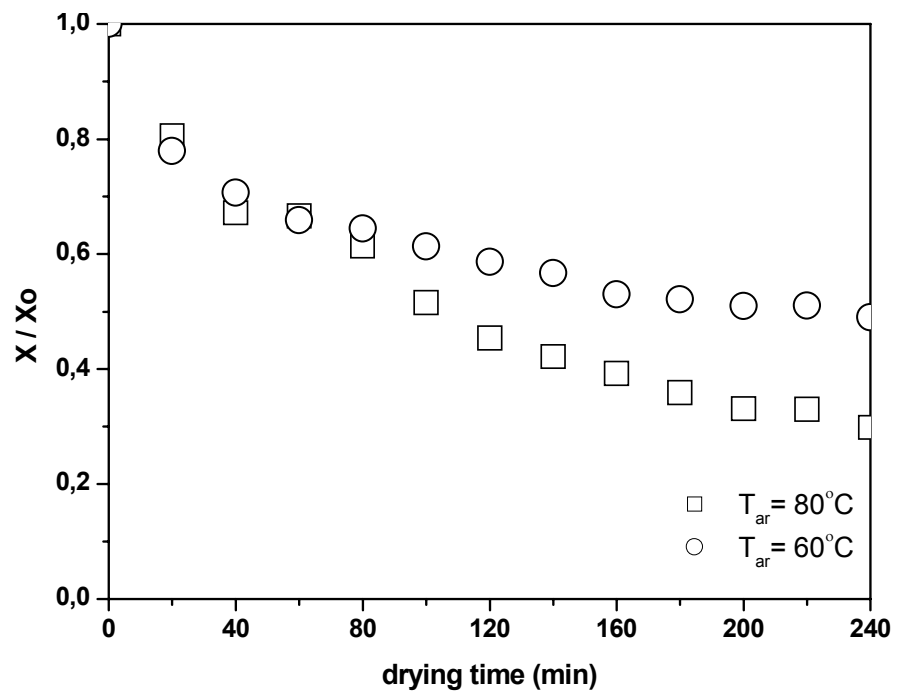

Figure 3: Effect of air temperature on the drying kinetics. Conditions: $\mathrm{t}_{\mathrm{i}}=40 \mathrm{~min} ; \mathrm{X}_{0}=30 \% \mathrm{db}-$ Drying Process I - Spouted/fixed bed 


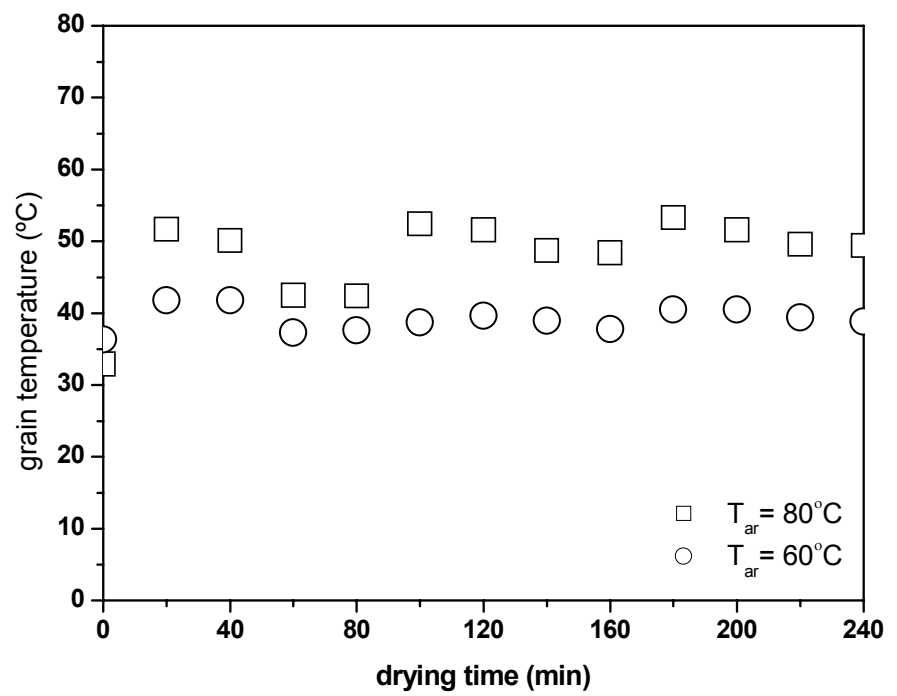

Figure 4: Effect of air temperature on grain temperature. Conditions: $\mathrm{t}_{\mathrm{i}}=40 \mathrm{~min} ; \mathrm{X}_{0}=30 \% \mathrm{db}-$ Drying Process I - Spouted/fixed bed

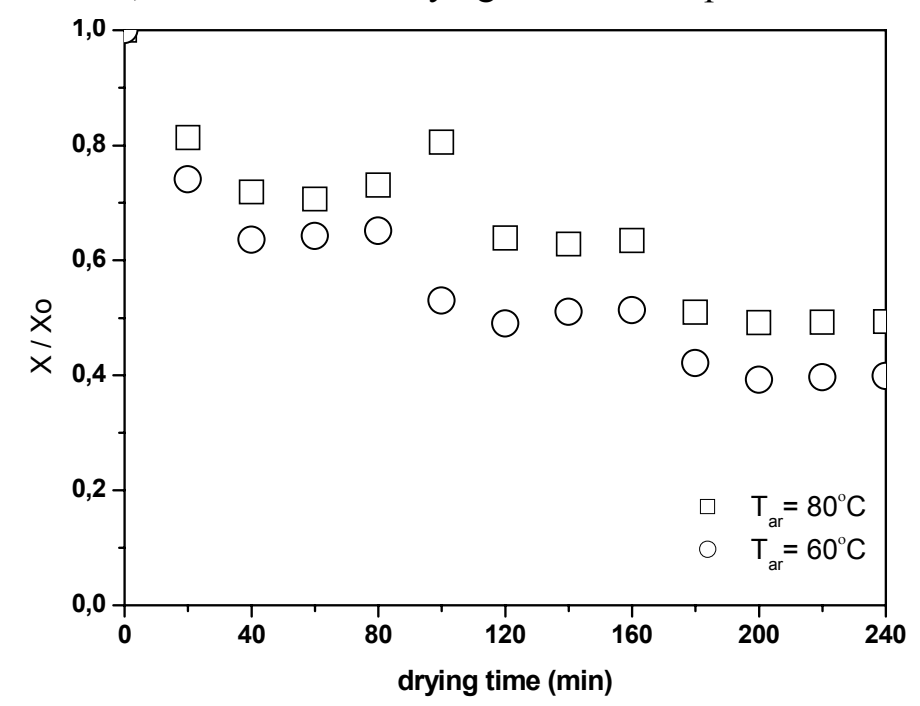

Figure 5: Effect of air temperature on the drying kinetics. Conditions: $\mathrm{t}_{\mathrm{i}}=40 \mathrm{~min} ; \mathrm{X}_{0}=30 \% \mathrm{db}-$ Drying Process II - Spouted bed $/$ rest

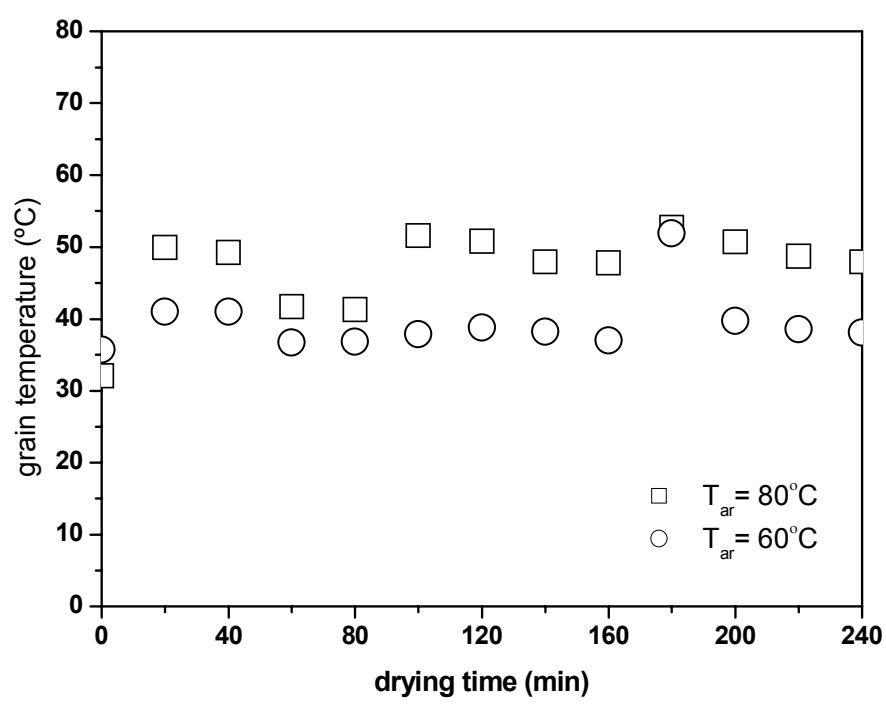

Figure 6: Effect of air temperature on grain temperature. Conditions: $\mathrm{t}_{\mathrm{i}}=40 \mathrm{~min} ; \mathrm{X}_{0}=30 \% \mathrm{db}$ - Drying Process II - Spouted bed $/$ rest 
The graphics in Figure 3 show the effect of air temperature on the drying curve for process I. A significant effect of $T_{a r}$ was verified, especially for drying times over $40 \mathrm{~min}$. These results were expected, as the temperature affected the falling rate period of the drying process the most.

It is important to point out that some experiments had drying curves showing rewetting points, due to the condensation of steam inside the bed during the intermittence period. These points occurred particularly for process II (Figures 5 and 6), where the air supply was totally interrupted in the intermittence period. These rewetting points were shown more explicitly, mainly, in the drying experiments that operated with a high initial moisture content of the grains, of around $30 \% \mathrm{db}$.

The curves in Figure 4 are examples of variation in grain temperature with drying time and air temperature. A decrease in grain temperature can be observed during the intermittence periods, and high air temperature resulted in high grain temperature. A parametric analysis was also carried out for initial moisture content of the grains and intermittence time. It was observed that the drying rate increased at higher initial moisture contents due to the higher moisture gradient between the grains and the drying air (Figure 7).

The intermittence time, as applied in this work, did not show a significant effect on the drying and grain temperature curves (the curves are practically coincident for $t_{i} 20 \mathrm{~min}$ and $40 \mathrm{~min}$ ). Similar behaviors were obtained for both processes I and II.

Analysis of Figures 3, 5 and 7 allows the observation that the spouted bed/rest drying intermittence, process II, generated lower drying rates, while for process I higher drying rates were verified for the same operating conditions. It was also verified that the experiments conducted under the conditions in Figure 7 had higher rates, strongly affected by the temperature of the drying air and then by the effect of the initial moisture contents of the bean grains.

The effects of the drying operating conditions $\mathrm{T}_{\mathrm{ar}}$, $\mathrm{X}_{0}$ and $\mathrm{t}_{\mathrm{i}}$ on the final moisture content ratio were statistically analyzed, using the factorial design technique, for processes I and II. The same final drying time of $240 \mathrm{~min}$ was fixed for all the experiments.

The statistical analysis was applied to the results in Tables 2 and 3 to determine the effects of the operating conditions on the response $\mathrm{X}_{\mathrm{f}} / \mathrm{X}_{0}$. The significance of the calculated effects on the responses is easily visualized using Pareto diagrams (Box et al., 1978). Figures 8 and 9 show the Pareto diagrams obtained to analyze the significance of effects $\mathrm{T}_{\mathrm{ar}}, \mathrm{X}_{0}$ and $\mathrm{t}_{\mathrm{i}}$ on the final moisture ratio, $\mathrm{X}_{\mathrm{f}} / \mathrm{X}_{0}$, for processes I and II.

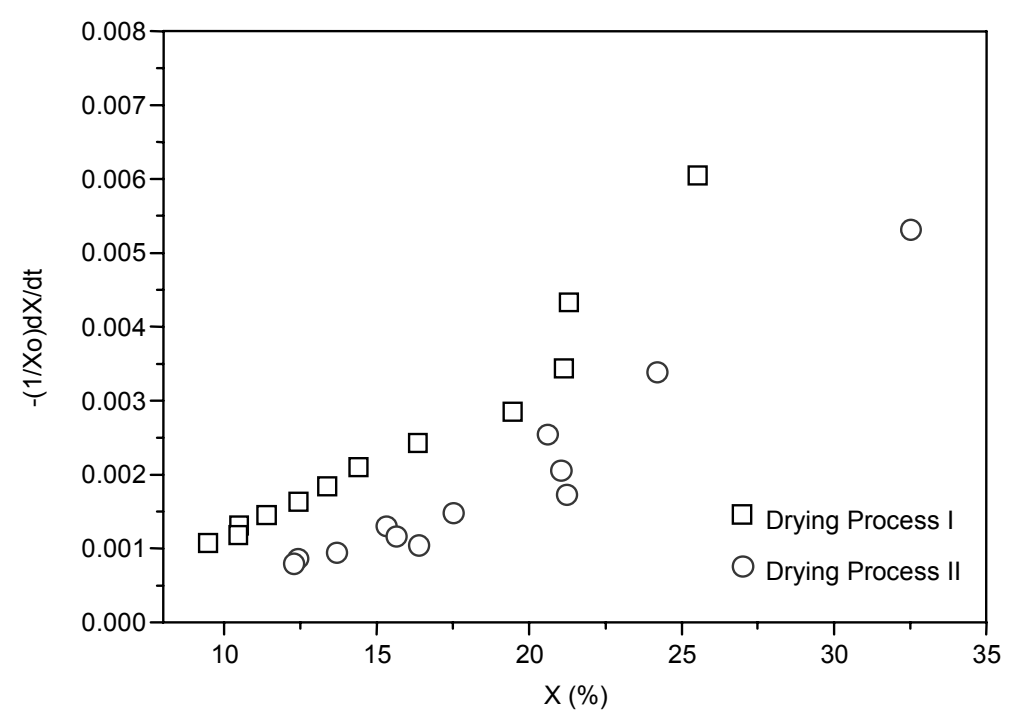

Figure 7: Graphic representation of the drying rates $\mathrm{T}_{\mathrm{ar}}=80^{\circ} \mathrm{C} ; \mathrm{X}_{0}=30 \% \mathrm{db}$; $t_{i}=40 \mathrm{~min}-$ for both intermittent processes 


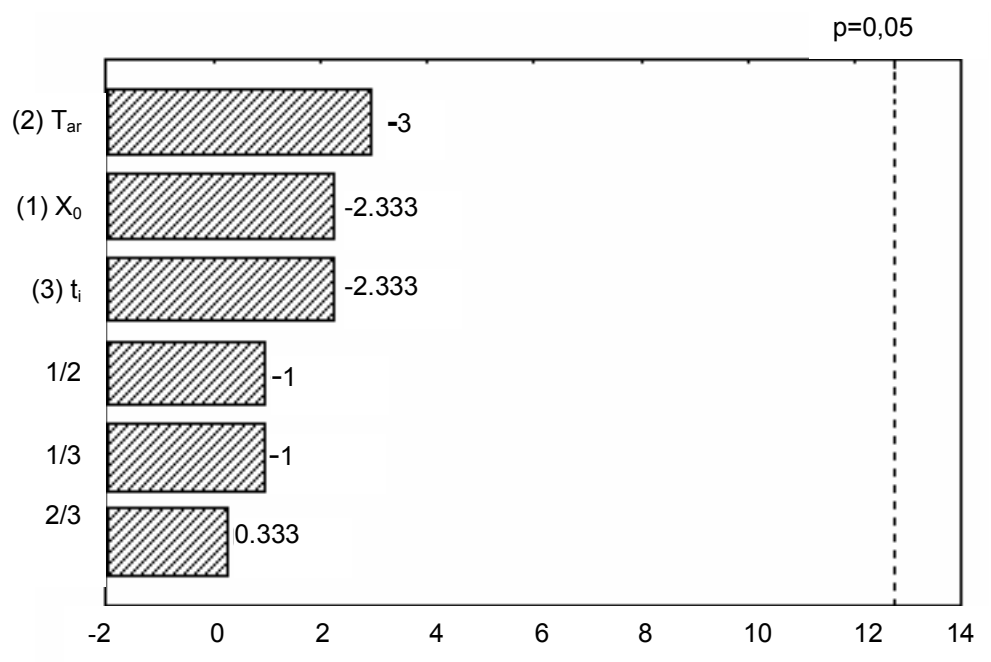

Figure 8: Pareto diagram of the estimated effects - response: final moisture ratio, $\mathrm{X}_{\mathrm{f}} / \mathrm{X}_{0}-$ Drying process I - Spouted/fixed bed

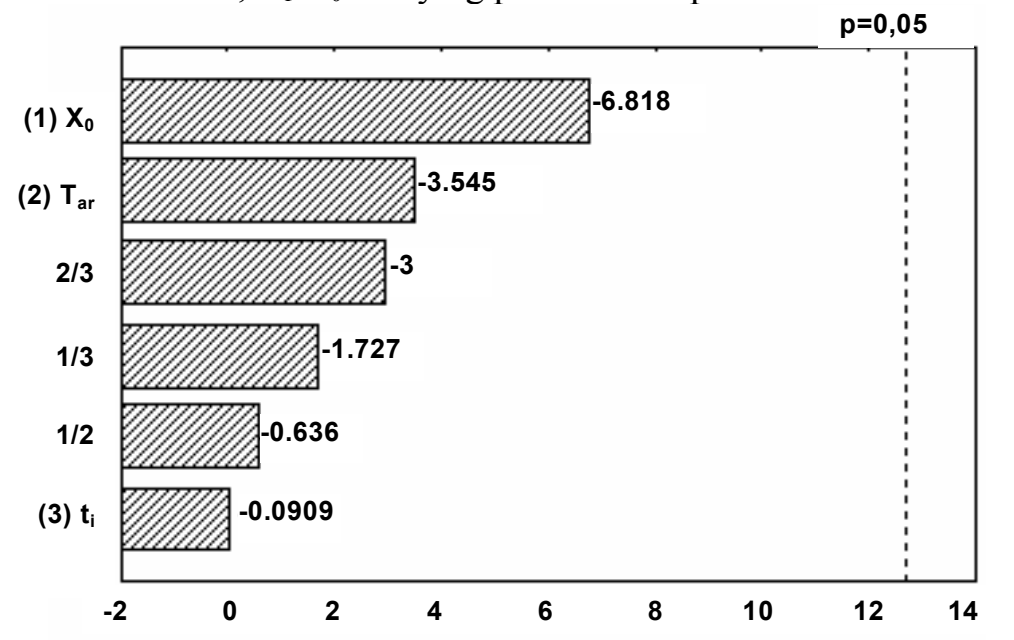

Figure 9: Pareto diagram of the estimated effects - response: final moisture ratio, $\mathrm{X}_{\mathrm{f}} / \mathrm{X}_{0}$ - Drying process II - Spouted bed/rest

It can be seen that for the range of experimental conditions tested, the drying operating conditions $\mathrm{T}_{\mathrm{ar}}$, $\mathrm{X}_{0}$ and $\mathrm{t}_{\mathrm{i}}$ or their combined effects did not have a significant effect on the final moisture content ratio at a significance level of $95 \%$, considering the Student's $t$-test, in spite of the higher values of the effects obtained for process II.

\section{Analysis of Drying Energy}

The effects of the drying operating conditions $\mathrm{T}_{\mathrm{ar}}$, $\mathrm{X}_{0}$ and $\mathrm{t}_{\mathrm{i}}$ on the energy coefficients and drying efficiency were statistically analyzed using the factorial design technique for processes I and II. The same drying time of 240 min was fixed for all the experiments.
The three variables, $T_{a r}, X_{0}$ and $t_{i}$, were fixed at two levels, specified for the experimental conditions shown in Tables 2 and 3. Table 4 shows the values of DE, DC and FC, obtained by applying Equations (2), (11) and (12), respectively. The calculations were done for processes I and II.

An analysis of the results presented in Table 4 shows that high values of drying efficiency, DE, were obtained for $\mathrm{T}_{\mathrm{ar}}=80^{\circ} \mathrm{C}, \mathrm{X}_{0}=20$ or $30 \% \mathrm{db}$ and $\mathrm{t}_{\mathrm{i}}=40 \mathrm{~min}$, for both processes I and II. A high intermittence time (maintaining the dryer in fixed bed regime or interrupting the entrance of air) caused a decrease in the total energy supplied to the grains, while the high values of air temperature and initial grain moisture content caused an increase in the mass of moisture evaporated, thus increasing the 
energy drying efficiency. It can also be verified that a high value of $\mathrm{DE}$ was obtained at $\mathrm{T}_{\mathrm{ar}}=60^{\circ} \mathrm{C}, \mathrm{X}_{0}=$ 20 or $30 \% \mathrm{db}$ and $t_{i}=20 \mathrm{~min}$. in process II. This result indicates that the low total energy input (low air temperature and interruption of the air to the dryer) did not jeopardize the evaporation of moisture. Comparing processes I and II, the drying energy efficiency was higher for process II, under all operating conditions.

Statistical analysis was applied to the results presented in Table 4 to define the effects of the operating conditions on the responses: DE, DC and FC. The significance of effects $T_{a r}, X_{0}$ and $t_{i}$ on the responses is shown by the Pareto diagrams in Figures 10 to 12.

Table 4: Drying efficiency and energy coefficients: Spouted/fixed bed and spouted bed/rest regimes

\begin{tabular}{|c|c|c|c|c|c|c|}
\hline \multicolumn{4}{|c|}{ Drying process I - Spouted / fixed bed } & \multicolumn{3}{|c|}{ Drying process II - Spouted bed/rest } \\
\hline Run & $\begin{array}{l}\text { DE } \\
(\%)\end{array}$ & $\begin{array}{c}\text { DC } \\
(\mathrm{kg} / \mathrm{kW}) .10^{5}\end{array}$ & $\begin{array}{c}\text { FC } \\
(\%)\end{array}$ & $\begin{array}{l}\text { DE } \\
(\%)\end{array}$ & $\begin{array}{c}\text { DC } \\
(\mathrm{kg} / \mathrm{kW}) \cdot 10^{5}\end{array}$ & $\begin{array}{c}\text { FC } \\
(\%)\end{array}$ \\
\hline 1 & 14.81 & 1.33 & 3.59 & 21.06 & 1.98 & 5.37 \\
\hline 2 & 11.83 & 1.32 & 3.57 & 17.18 & 1.72 & 4.67 \\
\hline 3 & 5.19 & 1.51 & 3.94 & 7.39 & 2.10 & 5.47 \\
\hline 4 & 7.04 & 1.06 & 2.76 & 7.76 & 1.63 & 4.25 \\
\hline 5 & 10.60 & 1.08 & 2.94 & 15.69 & 1.27 & 3.49 \\
\hline 6 & 9.21 & 1.06 & 2.88 & 11.15 & 1.43 & 3.93 \\
\hline 7 & 10.35 & 0.95 & 2.47 & 23.47 & 1.34 & 3.47 \\
\hline 8 & 12.66 & 0.94 & 2.46 & 16.02 & 1.19 & 3.09 \\
\hline
\end{tabular}

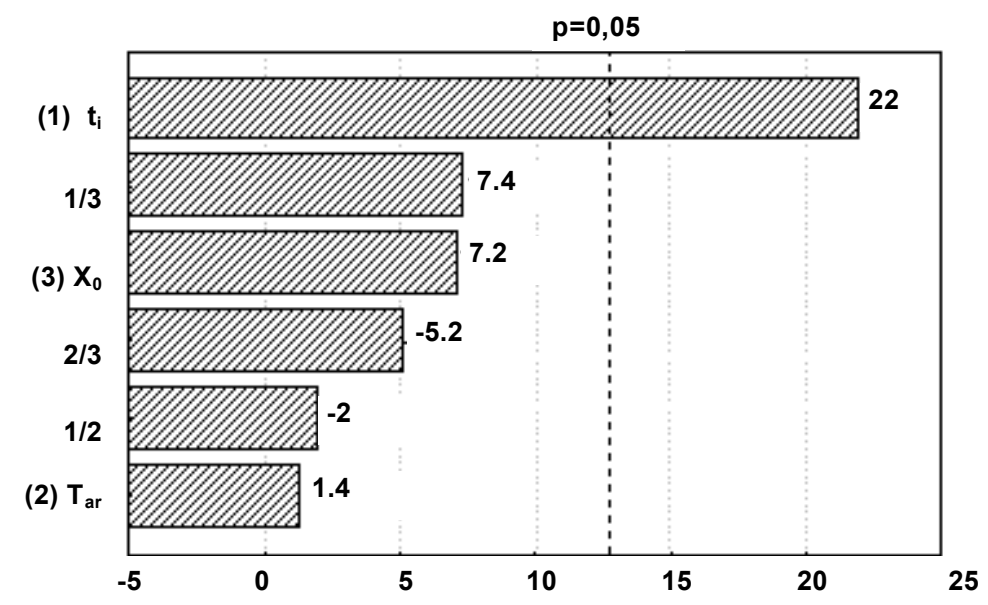

Figure 10: Pareto diagram of the estimated effects - response DE - Drying Process I - Spouted/fixed bed

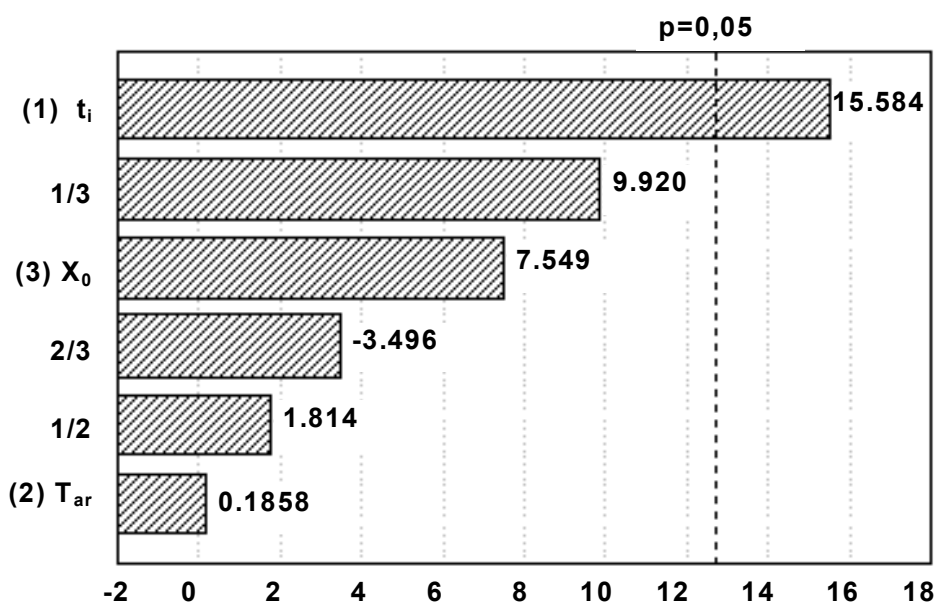

Figure 11: Pareto diagram of the estimated effects - response DC - Drying process II - Spouted bed/rest 


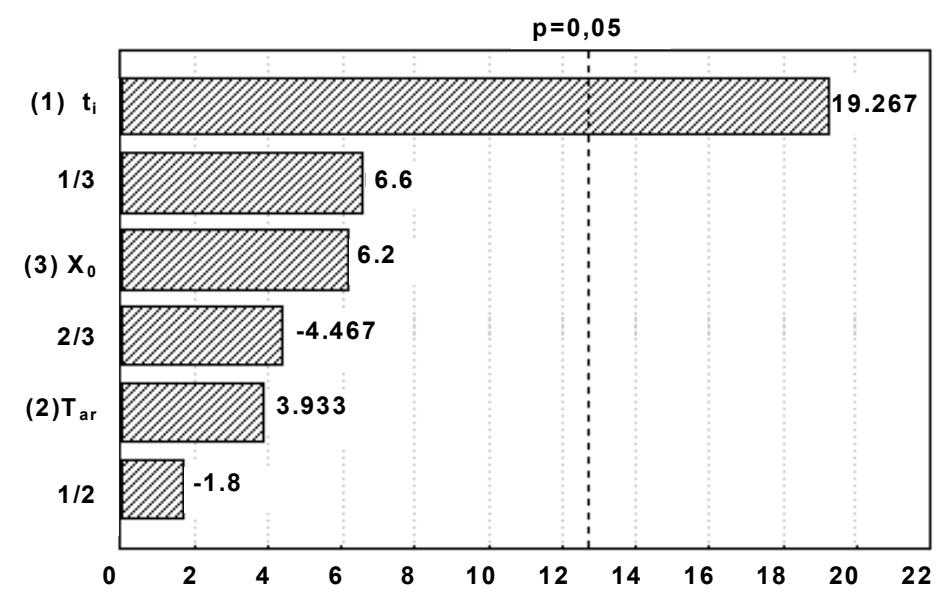

Figure 12: Pareto diagram of the estimated effects - response FC - Drying process - II-Spouted bed/rest

Figure 10 shows the Pareto diagram obtained for drying efficiency, DE, for process I. Significant combined effects of $\mathrm{T}_{\mathrm{ar}}-\mathrm{t}_{\mathrm{i}}$ can be verified at a significance level of $95 \%$, considering the Student's $t$-test. No significant effect at this level of confidence was verified for process II.

The highest values of coefficients $\mathrm{DC}$ and $\mathrm{FC}$ were obtained for conditions in run $3: \mathrm{T}_{\mathrm{ar}}=60^{\circ} \mathrm{C}, \mathrm{X}_{0}$ $=30 \% \mathrm{db}$ and $t_{i}=40 \mathrm{~min}$. The high value of intermittence time caused a decrease in the total energy input and also resulted in a decrease in mechanical energy, thus favoring the increase in coefficients DC and FC. The results in Table 4 also show that the highest values of the coefficients were obtained in the experiments with $t_{i}=40 \mathrm{~min}$.

Figures 11 and 12 contain Pareto diagrams for responses $\mathrm{DC}$ and $\mathrm{FC}$ in process II. A statistical analysis shows the significant effect of $t_{i}$ on both coefficients at a significance level higher than 95\%. The same result was verified for process I. The results in Table 4 and the ones presented in Figures 5 and 6 show that the intermittence applied to the spouted bed drying process had an important effect on the energy drying efficiency and coefficients, without jeopardizing the drying performance in the range of conditions applied in this work.

\section{A Comparison of Drying Performance - Intermittent and Continuous Drying}

To compare the results obtained in this work with those for the spouted bed drying of beans (Lima and Rocha, 1998; Lima, 1996), Table 5 and Figures 13 to 16 are presented.

Figures 13 to 16 show comparisons between the drying kinetics in the fixed bed and the spouted bed with and without intermittence. It can be seen that lower grain temperatures were obtained when intermittent process II was applied, which is a satisfactory result, since lower grain temperatures are required to maintain the physical and chemical properties of the grains unchanged. The drying kinetics are almost the same for the fixed and the spouted bed and different behaviors are observed for intermittent processes I and II. Points of rewetting appear for intermittent process II (spouted bed/rest), and consequently, moisture content of the beans is higher at the same drying time for this type of intermittence. For intermittent process I (spouted/fixed bed), the rewetting points are not so evident, but still a higher moisture content is observed at the same drying time than when the drying was conducted in the spouted and the fixed beds. The tendency to attain the same value of equilibrium moisture content is observed in all cases, indicating the viability of the intermittent processes applied.

The final moisture contents at 240 min of drying, obtained in all processes analyzed are close for the same operating conditions, especially for the spouted bed and the spouted/fixed bed (process I). All values obtained for $X_{f}$ are in the range defined as good conditions for carioca beans storage.

A comparison of the drying energy efficiencies and coefficients is shown in Table 5 and had the following order: spouted bed/rest > spouted/fixed bed $>$ spouted bed, thus supporting the choice of the intermittent spouted bed/rest process to obtain low energy consumption or high energy efficiency.

The values obtained for energy efficiencies and coefficients are close to the values found for industrial continuous convective dryers (Raghavan et al., 2004) and convective recycled paper drying (Vieira et al., 2005). 
Table 5: Comparison of drying processes in a spouted bed without and with intermittence

\begin{tabular}{|c|c|c|c|c|c|c|c|}
\hline \multicolumn{8}{|c|}{ Process - Spouted bed [Lima and Rocha, 1998] } \\
\hline $\begin{array}{l}\mathbf{T}_{\text {ar }} \\
\left({ }^{0} \mathrm{C}\right) \\
\end{array}$ & $\begin{array}{c}\mathrm{X}_{0} \\
(\% \mathrm{odb})\end{array}$ & Grain Mass (g) & $\begin{array}{c}W_{\mathrm{ar}} \\
(\mathrm{kg} / \mathrm{min})\end{array}$ & $\begin{array}{c}X_{f} \\
(\% \text { db })\end{array}$ & $\begin{array}{l}\text { DE } \\
(\%)\end{array}$ & $\begin{array}{c}\mathrm{DC} \\
(\mathrm{kg} / \mathrm{kW}) 10^{5}\end{array}$ & $\begin{array}{c}\text { FC } \\
(\%)\end{array}$ \\
\hline 83 & 20 & 3000 & 2.27 & 9.13 & 7.56 & 1.6 & 1.04 \\
\hline 83 & 30 & 3000 & 2.33 & 9.25 & 9.29 & 2.5 & 1.66 \\
\hline \multicolumn{8}{|c|}{ Drying Process I - Spouted/Fixed bed } \\
\hline 80 & 20 & 3200 & 2.44 & 9.02 & 11.83 & 1.32 & 3.57 \\
\hline 80 & 30 & 3200 & 2.44 & 9.17 & 14.81 & 1.33 & 3.59 \\
\hline \multicolumn{8}{|c|}{ Drying Process II - Spouted bed/Rest } \\
\hline 80 & 20 & 3200 & 2.44 & 11.58 & 17.18 & 1.72 & 4.67 \\
\hline 80 & 30 & 3200 & 2.44 & 11.85 & 21.06 & 1.98 & 5.37 \\
\hline
\end{tabular}

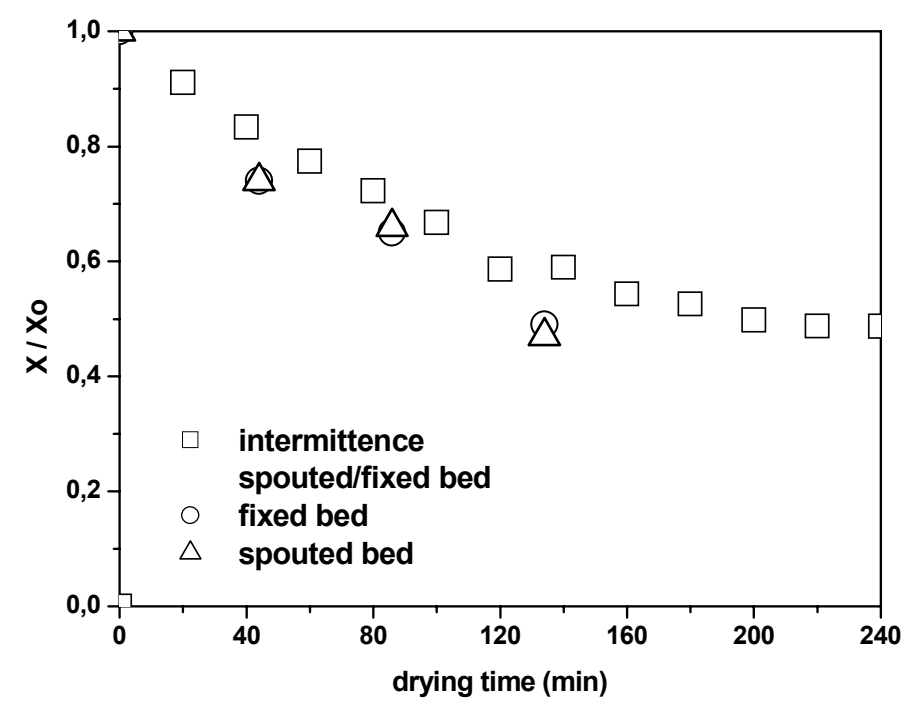

Figure 13: Comparison of drying curves for carioca beans in fixed and spouted beds with and without intermittence $\left(\mathrm{T}_{\mathrm{ar}}=80^{\circ} \mathrm{C} ; \mathrm{X}_{0}=20 \% \mathrm{db} ; \mathrm{t}_{\mathrm{i}}=40 \mathrm{~min}\right)$

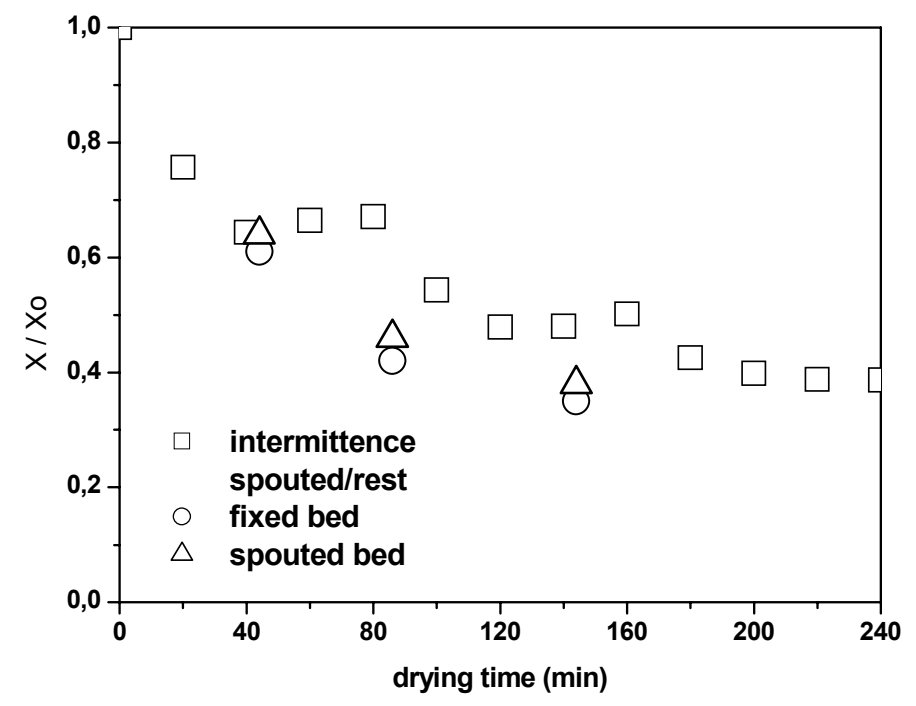

Figure 14: Comparison of drying curves for carioca beans in fixed and spouted beds with and without intermittence $\left(\mathrm{T}_{\mathrm{ar}}=80^{\circ} \mathrm{C} ; \mathrm{X}_{0}=30 \% \mathrm{db} ; \mathrm{t}_{\mathrm{i}}=40 \mathrm{~min}\right)$ 


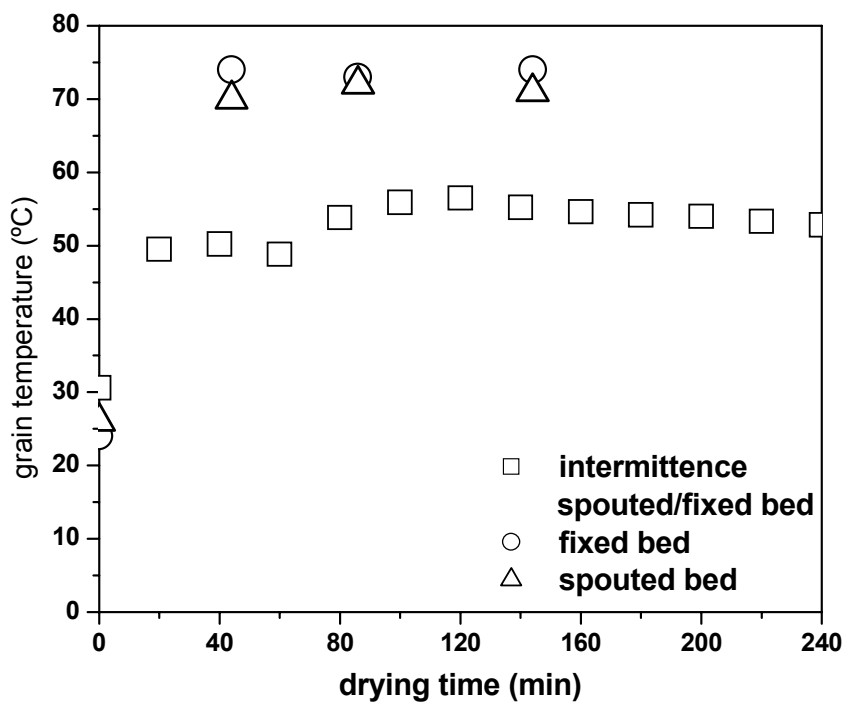

Figure 15: Comparison of grain temperature of carioca beans in fixed and spouted beds with and without intermittence $\left(\mathrm{T}_{\mathrm{ar}}=80^{\circ} \mathrm{C} ; \mathrm{X}_{0}=20 \% \mathrm{db} ; \mathrm{t}_{\mathrm{i}}=40 \mathrm{~min}\right)$

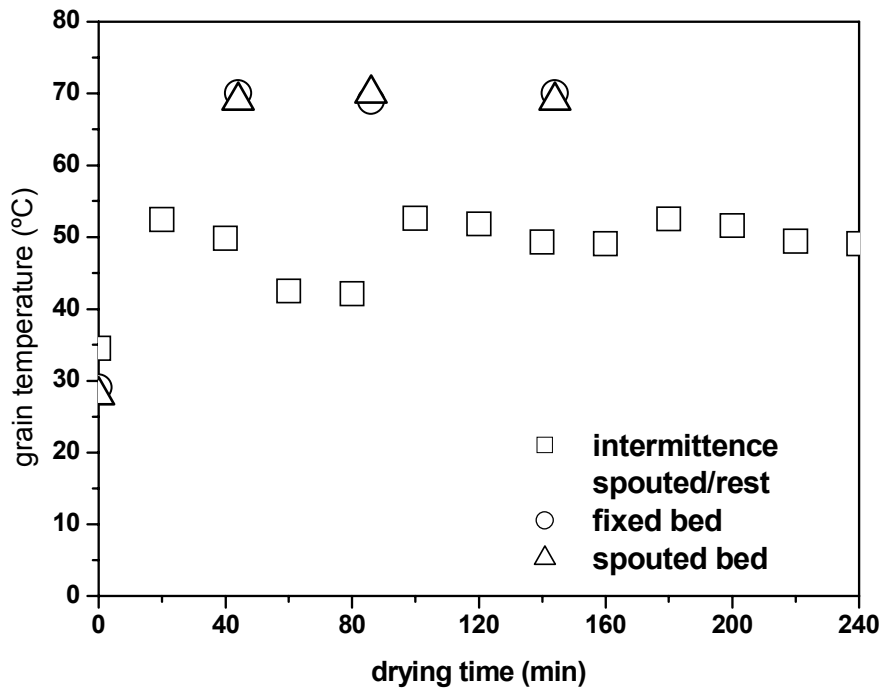

Figure 16: Comparison of grain temperature of carioca beans in fixed and spouted beds with and without intermittence $\left(\mathrm{T}_{\mathrm{ar}}=80^{\circ} \mathrm{C} ; \mathrm{X}_{0}=30 \% \mathrm{db} ; \mathrm{t}_{\mathrm{i}}=40 \mathrm{~min}\right)$

\section{CONCLUSIONS}

The experimental results obtained in this work for the drying of beans in a spouted bed under intermittent conditions led to the following conclusions:

- The results of the statistical analysis of the drying kinetics showed that the intermittence period, air temperature and initial grain moisture content did not have significant effects on the final moisture ratio at a significance level of 95\% (Student's $t$-test), in the range of conditions applied in this work.

- At 240 min of drying, the final moisture contents of the grains, obtained by intermittent drying were in the range considered as good storage conditions for the beans.

- Lower bean temperatures were obtained for the two types of intermittent drying process applied than for the fixed bed and the spouted bed processes under continuous and constant hot air supply.

- The drying curves for the intermittent processes tested show the same behavior (falling rate period) as the ones obtained with the spouted and the fixed bed without intermittence. However, rewetting of the grains was observed during the intermittent drying, mostly for the spouted bed/rest process. Thus, a too long period of intermittence can jeopardize the drying, causing the final moisture content of the 
product to be too high.

- The drying energy efficiency and coefficients had the following order: spouted bed/rest $>$ spouted/fixed bed $>$ spouted bed, thus supporting the choice of the intermittent spouted bed/rest process to obtain the lowest energy consumption.

- Intermittence is a promising technique for the drying of beans and grains in general due to the gain in energy efficiency and to the good quality of the product obtained, showing appropriate value and homogeneous moisture content and temperature when the bed is periodically spouted.

\section{ACKNOWLEDGMENTS}

The authors acknowledge the financial support received from CAPES and FAPESP to develop this research.

\section{NOMENCLATURE}

$\begin{array}{llr}\text { c } & \text { specific heat, } & \mathrm{J} \mathrm{kg}^{-1} \mathrm{~K}^{-1} \\ \text { DC } & \text { drying coefficient, } & \mathrm{kg} \mathrm{water} \mathrm{s}^{-1} / \mathrm{W} \\ \text { DE } & \text { drying efficiency, } & (-) \\ \text { E } & \text { energy/time, } & \mathrm{W} \\ \text { EM } & \text { mechanical energy flux, } & \mathrm{W} \\ \text { ET } & \text { total energy/time, } & \mathrm{W} \\ \text { FC } & \text { fluid dynamic drying } & (-) \\ & \text { coefficient, } & \mathrm{kg} \\ \text { m } & \text { mass, } & \mathrm{m} / \mathrm{s} \\ \text { Q } & \text { air flow rate, } & \mathrm{min} \\ \text { t } & \text { time, } & { }^{\circ} \mathrm{C} \\ \text { T } & \text { temperature, } & \mathrm{kg} / \mathrm{s} \\ \text { W } & \text { mass flow rate, } & \% \mathrm{db} \\ \text { X } & \text { moisture content, } & \mathrm{J} / \mathrm{kg} \\ \Delta \mathrm{H} & \text { latent heat of vaporization, } & \mathrm{N} / \mathrm{m}^{2} \\ \Delta \text { P } & \text { bed pressure drop, } & (-) \\ \phi & \text { sphericity, } & \end{array}$

\section{Subscripts}

$\begin{array}{ll}\text { amb } & \text { ambient air } \\ \text { ar } & \text { air } \\ \text { d } & \text { drying } \\ \text { f } & \text { final } \\ \text { g } & \text { grain } \\ \text { h } & \text { heating } \\ \text { i } & \text { intermittence } \\ 0 & \text { initial } \\ \text { ter } & \text { thermal }\end{array}$

$\begin{array}{ll}\text { V } & \text { Vaporization } \\ \text { W } & \text { water }\end{array}$

\section{REFERENCES}

Box, G.E.P., Hunter, J.H., Hunter, W.G. 1978. Statistics for experimenters - An introduction to design, data analysis and model building, New York: John Wiley \& Sons.

Cavalcanti Mata, M.E.R.M., 1997. Effect of high temperature-short time stationary bed drying on the conditioning of bean seeds (Phaseolus vulgaris L.), "carioca" variety: Experimental analyses, modeling and simulation, Ph.D. Diss., State University of Campinas, Campinas, Brazil (in Portuguese).

Dewettinck, K., Messens, W., Deroo, L., Huyghebaert, A., 1999. Agglomeration tendency during top-spray fluidized bed coating with gelatin and starch hydrolysate. Lebensm-Wiss. UTechnol., 32: 102-106.

Inprasit, C., Noomhorm, A., 2001. Effect of drying air temperature and grain temperature of different types of dryer and operation on rice quality. Drying Technology 19 (2): 389-404.

Jumah, R.Y., Mujumdar, A.S., 1996. A mathematical model for constant and intermittent batch drying of grains in a novel rotating jet spouted bed. Drying Technology 14 (3-4): 765-803.

Lajolo, M.F., Genovese, I.M., Menezes, W.E., 1996. Nutritional quality and cultivation of beans in Brazil. Piracicaba: Potafos (in Portuguese).

Lima, A.C.C., 1996. Experimental analysis of the bean drying in fixed bed, spouted bed and spouted bed. M. Sc. Thesis, State University of Campinas, Campinas, Brazil (in Portuguese).

Lima, A.C.C., Rocha, S.C.S., 1998. Bean drying in fixed, spout and spout-fluid beds: Comparison and empirical modeling. Drying Technology 16 (9-10): 1881-1902.

Madhiyanon, T., Soponronnarit, S., Tia, W., 2001. A two-region model for batch drying of grains in a two-dimensional spouted bed. Drying Technology 19 (6): 389-404.

Madhiyanon, T., Soponronnarit, S., Tia, W., 2002. A mathematical model for continuous drying of grains in a spouted bed dryer. Drying Technology 20 (3): 587-614.

Mohsenin, N.N., 1978. Physical proprieties of plant and animal materials. New York: Gordon and Breach Publishers.

Muthu, V.P. and Chattopadhyay, P.K., 1993. 
Prediction of heat of vaporization of moisture from cereals grains - a modelling approach. Drying Technology, 11 (7): 1855-1862.

Pakowski, Z., Mujumdar, A.S., 1995. Basic process calculations in drying. Handbook of Industrial Drying. Ed. A.S. Mujumdar, 1: 71-112.

Raghavan, V.G.S., Rennie, T.J., Sunjka, P.S., Orsat, V., Phaphuangwittayakul, W., Terdtoon, P., 2004. Energy aspects of novel techniques for drying biological materials. Drying 2004. Proceedings of the $14^{\text {th }}$ International Drying Symposium (IDS 2004), Eds. M.A. Silva and S.C.S. Rocha, São Paulo, B: 1021-1028.

Robins, P.T., Fryer, P.J., 2003. The spouted bed roasting of barley: Development of a predictive model for moisture and temperature. Journal of Food Engineering 59 (2-3): 199-208.

Sangkram, U., Noomhorm, A., 2002. The effect of drying and storage of soybean on the quality of bean, oil and lecithin production. Drying
Technology 20 (10): 2041-2054.

Strumillo, C., Kudra, T., 1986. Drying: Principles, Application and Design. Montreux: Gordon and Breach Science Publishers.

Vieira, M.G.A., Estrella, L., Rocha, S.C.S., 2005. Energy efficiency and drying kinetics of recycled paper in convective drying, Proceedings of the $3^{\text {rd }}$ Inter American Drying Conference (IADC 2005), Montreal, CD-ROM.

Wachiraphansakul, S., Devahastin, S., 2005. Drying kinetics and quality of soy residue (Okara) dried in a jet spouted bed dryer. Drying Technology 23 (6): 1229-1242.

Welty, J.R., Wicks, C.E., Wilson, R. E., 1984. Fundamentals of Momentum, heat and mass transfer. $3^{\text {rd }}$ ed, New York: John Wiley \& Sons.

Wiriyaumpaiwong, S., Soponronnarit, S., Prachayawarakorn, S., 2003. Soybean drying by two-dimensional spouted bed. Drying Technology 21 (9): 1735-1757. 